http://dx.doi.org/10.4314/jae.v18i1.4

\title{
Adoption of Green River Project Fish Farming Technologies by Farmers in Niger Delta Region of Nigeria
}

\section{Ogbonna O.I ${ }^{1}$, Onwubuya E. $A^{2}$ and Akinnagbe O.M ${ }^{3}$}

Department of Agricultural Extension, University of Nigeria, Nsukka

Mobile: $+2348061591391^{1} ;+2348094096400^{2}$; and $+2348035399151^{3}$ onyinyechi.ogbonna@unn.edu.ng ${ }^{1}$; lizzybuya@yahoo.com ${ }^{2}$;

oluwole.akinnagbe@unn.edu.ng

\section{Abstract}

The study assessed adoption of improved fish farming technologies by fish farmers as well as socioeconomic characteristics of respondents, level of adoption of GRP fish farming technologies and constraints to adoption of the technologies. The hypothesis of the study was that socioeconomic conditions of farmers do not significantly influence adoption of GRP technologies. Multistage sampling technique was used to select 120 respondents from two states in Niger Delta. Descriptive statistics, regression analysis and factor analysis were used to analyze data. Results showed that majority (76.7\% and $77.5 \%)$ of the fish farmers were male and married respectively. Mean age of the respondents was 50 years and majority were literates. Majority of the respondents adopted fish farm management technologies (79\%), feeding techniques (79\%), fish culture management techniques (77\%) and water quantity and quality management techniques (88\%). Constraints to adoption of the technologies included technology- related constraints such as existence of technologies better than GRP technologies (with loading of 0.536) and input- related constraints such as: late arrival of GRP input (0.760). Result of the hypothesis was that some socioeconomic characteristics of farmers (age and years spent in school) affected adoption. It was recommended that there should be involvement of youths in the project, provision of sufficient inputs to farmers at the right time and measures to increase collaboration between GRP and other agencies that disseminate improved fish farming technologies in the area.

Keywords: GRP, Technology, fish farming

\section{Introduction}

The major problem of fish farming has been the lack of appropriate technology (Gupta, Bartley \& Acosta, 2004). Agricultural extension services help to disseminate technologies and encourage farmers to adopt them. According to Rogers (2003), adoption is a decision of full use of an innovation as the best course of action available. In order to improve adoption of technologies, it is important to make the content more relevant to farmers. It is also important to develop sustainable financing option, use well trained and adequate staff, and use participatory extension approach under stable policy and sustainable institutional arrangement (Koyenikan, 2008).

Development of agriculture and fish farming can be enhanced through introduction of modern technologies (Nwachukwu and Onuegbu, 2007). According to Amaniyie (2006), agriculture which is the major occupation and main source of income to rural indigenes of the Niger Delta states was negatively affected by the operation of oil exploratory companies. Hence agricultural extension services of oil exploration companies in the area were initiated as important tools to improve agricultural production in these communities. Green River Project (GRP) agricultural extension service delivery system operates in the land and swamp areas of Niger Delta (Rivers, Bayelsa and Delta States) and Imo State. The fish farm development component of GRP started its operations in 1999 (GRP, 2001). 
GRP has helped to disseminated improved fish farming technologies to enhance fish production and standard of living of beneficiary fish farmers.

However, despite the activities of GRP in Niger Delta, Nnodim and Isife (2004) reported that many farmlands, economic crops and trees and fishing waters in the region were barren. Agricultural production and fish farming have not improved in the area (Amaniye, 2006). Technologies disseminated to the farmers over many years by GRP include fish farm management technologies, feeding techniques, fish culture management techniques, pond water quality and quantity management and liming techniques. If these fishery technologies are properly disseminated by GRP, there ought to be increased adoption by the fish farmers.

\section{Purpose of the study}

The purpose of the study was to ascertain the adoption of GRP improved fish farming technologies. Specifically, the study sought to:

i. determine the level of adoption of GRP fishery technologies by GRP fish farmers and

ii. ascertain farmers perceived constraints to adoption of fish farming technologies disseminated.

The hypothesis of the study was that socio-economic characteristics of GRP fish farmers do not significantly influence the adoption of improved fish farming technologies.

\section{Methodology}

The study was carried out in Niger Delta, Nigeria. Niger Delta is characterized by extensive network of rivers and creeks that discharge their waters into the Atlantic Ocean (Tawari, et al, 2009). As a result, fishing is the major occupation of its inhabitants (Tawari, 2006 and Davies et al., 2008). All fish farmers in GRP constituted the population for the study. Multi-stage sampling technique was used to select the sample (120 respondents). Data were collected from fish farmers through the use of interview schedule.

To ascertain the farmers' adoption of fish farming technologies, a list of GRP fish farming technologies was provided for respondents to tick their level of adoption. A five point Likert type scale of "aware = 1"; "interest =2"; "evaluation=3"; "trial= 4" and "adoption $=5$ " was used to measure their responses. The adoption indices of respondents were calculated as follows:

i. computation of adoption means score: This was computed by dividing total adoption score by number of respondents involved.

ii. Grand mean score: this was computed as addition of individual technology adoption mean scores divided by number of technologies.

iii. computation of adoption index: this was computed by dividing the grand mean adoption score by 5 ( 5 stages of adoption).

Grand mean scores was used to indicate the respondent level in adoption process for each group of technologies like water quality management technologies and fish farm management technologies.

Hypothesis of the study was analyzed using regression analysis. The regression model is specified in the explicit form as follows:

$$
Y=\alpha+\beta_{1} X_{1}+\beta_{2} X_{2}+\beta_{3} X_{3}+\beta_{4} X_{4}+\beta_{5} X_{5}+\beta_{6} X_{6}+U
$$

Where: $Y=$ adoption score of GRP improved fish farming technologies; $\alpha=$ constant term; $\beta_{1}$ $-\beta_{7}=$ regression coefficients; $X_{1}=$ age (years); $X_{2}=$ Household size (actual number); $X_{3}=$ number of years spent in formal education; $X_{4}=$ years of participation in GRP (years); $X_{5}=$ membership of social organization (dummy: yes $=1, \mathrm{No}=0$ ); $\mathrm{X}_{6}=$ number of extension visit per month; $\mathrm{U}=$ error term 


\section{Results and discussion \\ Socio-economic characteristics of GRP fish farmers and GRP personnel}

Majority (63.3\%) of GRP fish farmers were between 41 and 60 years, while smaller proportions $(21.7 \%$ and $15.0 \%)$ of the farmers were between 21 and 40 years and 61 and 80 years, respectively. The mean age of GRP farmers was 50.3 years implying that they were middle aged and in their economically active stage. This is in line with Nlerum (2013) which showed that the mean age of beneficiaries of the GRP as 48 years. In his findings majority of the beneficiaries of the project were within the active and productive working age. When fish farmers are in the economically active age, they can make decisions and enhance their productivity.

Majority $(76.7 \%)$ of GRP fish farmers were male while $23.3 \%$ were female. This is in line with Nwosu, et al (2013) in which majority of the fish farmers were male. This indicates that male farmers dominate fish farming enterprise in the area. This could be due to the nature of fish farming which involves regular supervision and monitoring.

Majority $(77.5 \%)$ of GRP fish farmers were married while $12.5 \%$ were single. About $8 \%, 2 \%$ and $1 \%$ were widowed, separated and divorced respectively. This is in line with Nwosu, et al (2013) in which majority of the fish farmers were married. The implication is that there could be more support from spouses and children of the farmers with a view to improving and increasing fish production. This also implies that the fish farmers were responsible and had more roles to play in their families and as such they will be eager to improve their agricultural productivity.

Greater proportion $(46.7 \%)$ of GRP fish farmers had secondary education while $38.3 \%$ had first degree, $8.3 \%$ had higher degree qualification while $6.7 \%$ had primary education as their highest educational qualification. This shows that the respondents were literates at varying levels. This is in line with Nlerum (2013), who found that majority of GRP farmers had attempted or attained secondary school level of education implying that majority of them can easily decode and apply production recommendations on fish farming innovations of the project.

Majority $(70.0 \%)$ of GRP fish farmers engaged in fish farming as part time occupation. A smaller proportion (30.0\%) of the respondents practiced fish farming as fulltime occupation. For those that engaged in fish farming as their secondary occupation, about $22 \%, 18.3 \%, 17.5 \%$ and $12.5 \%$ engage in trading, animal production, poultry production and crop farming, respectively. This agrees with the findings of Apata (2012) that most fish farmers had other income generating activities ranging from civil service, trading and farming, hence implying that fishing activity can be combined with other income generating activities to make more income.

Majority (60.0\%) of the fish farmers had household size of between 6 and 10 persons. A smaller proportion (39.2\%) had household size of 1 and 5 persons while $8.0 \%$ had household size of 10 and 15 persons. The average household size was 6 persons. Average household size of 6 persons implies that GRP farmers had reasonable family size that could help in fish farming activities.

Majority (86.7\%) of GRP fish farmers belonged to a social organization while $13.3 \%$ did not belong to social organisation. Further analysis revealed that among those that belonged to social organization, majority $(75.0 \%)$ belonged to fish farmers cooperative, $30 \%$ belonged to thrift (Isusu) organisation while $20.8 \%$ belonged to one trader organization or the other. This is in line with the findings of Etuk, Ekanem, and Cookey (2012) which revealed that GRP work with farmers as cooperatives. Belonging to these social organisations help farmers to have enough farm credit to adopt important technologies. 
Majority (87.5\%) of the respondents had contact with GRP personnel between 1 and 5 times per month. A small proportion (12.5\%) had between 6 and 10 times per month. The average number of times the fish farmers had contact with GRP personnel in a month was 4 times. This slightly varied with findings of Aphunu and Otoikhian (2008), which stated that most of the farmers in Delta State agricultural development programme had contact with extension agents forth nightly and monthly. This shows that the respondents had frequent contact with GRP personnel. Frequent extension contact could facilitate continuous and proper use of adopted technologies.

Only $30.0 \%$ of the farmers had fish farming as their only source of income while majority $(70.0 \%)$ had other sources of income such as animal, crop and poultry production. It could be that the fish farmers had other sources of income in order to have access to credit at all times. This agrees with the opinion of Barrett, Reardon and Webb (2001), that very few people collect all their income from only one source, hold all their wealth in the form of any single asset, or use their resources in just one activity. The reason for diversification of their sources of income may be to ensure access to credit at all times.

Majority $(87.5 \%)$ of the respondents had participated in GRP activities for 6 to 10 years, while $12.5 \%$ had participated for between 1 and 5 years. The average number of years involved in GRP activities by the respondents was 8years. This agrees with the findings of Ogunlade, Oladele and Ogunsola (2009), which stated that majority of their respondents, got to know about the Green River Project innovations between 1991 and 1994 but the full participation by the majority was not evident until between 1999 and 2002. The implication of this is that the farmers have spent a good number of years with GRP. Hence, they should have learnt and/or adopted most of the GRP fish farming technologies. 
Table 1: Percentage distribution of respondents according to socioeconomic characteristics

\begin{tabular}{|c|c|c|c|c|}
\hline \multirow{4}{*}{$\begin{array}{l}\text { Variables } \\
\text { Age (years) }\end{array}$} & & Frequency & Percentage & Mean \\
\hline & $21-40$ & 26 & 21.7 & \\
\hline & $41-60$ & 76 & 63.3 & 50 \\
\hline & $61-80$ & 18 & 15.0 & \\
\hline \multirow[t]{3}{*}{ Sex } & Male & 92 & 76.7 & \\
\hline & Female & 28 & 23.3 & \\
\hline & Single & 15 & 12.5 & \\
\hline \multirow[t]{4}{*}{ Marital Status } & Married & 93 & 77.5 & \\
\hline & Divorced & 1 & 0.8 & \\
\hline & Widow/widower & 9 & 7.5 & \\
\hline & Separated & 2 & 1.7 & \\
\hline \multirow[t]{4}{*}{ Educational level } & Primary Education & 8 & 6.7 & \\
\hline & Secondary education & 56 & 46.7 & \\
\hline & HND/first degree & 46 & 38.3 & \\
\hline & $\begin{array}{l}\text { Higher degree (M.Sc and } \\
\text { PhD) }\end{array}$ & 10 & 8.3 & \\
\hline \multirow[t]{2}{*}{ Occupation } & Full time fish farming & 84 & 70.0 & \\
\hline & Part time fish farming & 36 & 30.0 & \\
\hline \multirow{4}{*}{$\begin{array}{l}\text { Secondary } \\
\text { occupation }(n=84)\end{array}$} & Crop farming & 15 & 12.5 & \\
\hline & Trading & 26 & 21.7 & \\
\hline & Animal production & 22 & 18.3 & \\
\hline & Poultry production & 21 & 17.5 & \\
\hline \multirow[t]{3}{*}{ Household size } & $1-5$ & 47 & 39.2 & 6.0 \\
\hline & $6-10$ & 72 & 60.0 & \\
\hline & $10-15$ & 1 & 8.0 & \\
\hline \multirow{2}{*}{$\begin{array}{l}\text { Membership of } \\
\text { social organization }\end{array}$} & Yes & 104 & 86.7 & \\
\hline & No & 16 & 13.3 & \\
\hline \multirow[t]{3}{*}{ Social organization } & trader organization & 25 & 20.8 & \\
\hline & Farmers cooperative & 90 & 75.0 & \\
\hline & Isusu/thrift organization & 36 & 30.0 & \\
\hline \multirow{2}{*}{$\begin{array}{l}\text { Sources of } \\
\text { income* }^{*}\end{array}$} & Fish farming & 36 & 30.0 & \\
\hline & $\begin{array}{l}\text { Others(crop, animal and } \\
\text { poultry farming) }\end{array}$ & 84 & 70.0 & \\
\hline \multirow[t]{2}{*}{ Participation GRP } & $1-5$ years & 15 & 12.5 & 8.0 \\
\hline & $6-10$ years & 105 & 87.5 & \\
\hline \multirow[t]{2}{*}{ Extension contact } & 1-5 times per month & 105 & 87.5 & 4.0 \\
\hline & $6-10$ times & 15 & 12.5 & \\
\hline
\end{tabular}

${ }^{*}$ multiple response 


\section{Adoption of GRP fish farming technologies by GRP fish farmers}

The adoption scores, grand mean scores and adoption indices of GRP fish farming technologies by the fish farmers were presented in Table 2 . The technologies include:

\section{Fish farm management technologies}

Adoption mean scores for fish farm management (proper site selection considering sources of good water; pond construction such as depth of $75 \mathrm{~cm}-2 \mathrm{~m}$ deep; proper use and provision of harvesting tools; good record keeping technique and training on the need for cooperative societies) by the fish farmers were $4.29,4.27,2.76,4.12$ and 4.40 respectively, out of a maximum of a 5-point scale. The grand mean adoption score for the five fish farm management technologies was 3.98, indicating that the fish farmers were at the trial level of the adoption process. The adoption index was $79.0 \%$. This implies that the adoption level of the farmers is above average. This agrees with Nwachukwu et al (2007) who indicated that about half of the respondents adopted pond construction practice and pond installation.

The high adoption mean score for the formation and use of cooperatives could be attributed to the fact that GRP personnel worked with fish farmers' cooperatives. Also, the low adoption mean score for the technology on provision and use of harvesting tools agrees with Tawari et al (2009 report that the programme of GRP, SPDC, ADP and Elf on fish gear usage and operation technique in Niger Delta had only $5.4 \%$ participation from respondents.

\section{Feeding techniques}

Adoption mean scores for feeding techniques (use of different sizes of feed like $0.5 \mathrm{~mm}$ at first week, use of good feed like copens, use of correct quantity of feed, how to produce locally made feed and use of good quality feed) by the fish farmers were 4.88 , $4.59,4.30,3.05$ and 2.44 respectively, out of a maximum of a 5-point scale. The grand mean adoption score for the fish farm management technologies was 3.85, indicating that the fish farmers were at the trial level of the adoption process. The adoption index was $77.0 \%$. This implies that the adoption level of the farmers is above average and this supports Apata (2012) who found that majority of fish farmers in south western Nigeria adopted good feeding technique.

The high adoption level could be attributed to the fact that good feeding techniques are necessary in order to enhance the productivity. The low adoption mean score of use of correct quantity of feed may be as a result of cost of feed which could make them to use quantity of feed they can afford.

\section{Fish culture management}

Adoption mean scores for fish culture management techniques (trainings on selection of good fish species like tilapia and catfish, stocking technique like avoiding overstocking, grading techniques, provision of fingerlings like tilapia and catfish, fish harvesting techniques, fish seed multiplication technique; medication and disease control; proper fertilization of ponds, and sourcing of credit) by the fish farmers were 4.70, 4.69, $4.59,4.26,3.83,2.84,3.05,3.32$ and 3.31 respectively, out of a maximum of a 5-point scale. The grand mean adoption score for the fish farm management technologies was 3.84 , indicating that the fish farmers were at the trial level of the adoption process. The adoption index was $77.0 \%$. This implies that the adoption level of the farmers is above average. This supports Tawari et al (2009) which stated that fish culture management like grading and sorting had highest percentage of farmers that fully benefitted and practiced the technologies. This helps to improve productivity and profitability in fish farming.

The high adoption level could be attributed to the fact that avoiding overstocking helps the fish farmers to prevent cannibalism and competition in their ponds in order to 
reduce production losses. Grading or sorting of the fish stocks at different stages are necessary to ensure that fishes mature at the same time.

\section{Water quality and quantity management}

Adoption mean scores for water quality and quantity management techniques (water testing to ensure quality standard, changing of bad water, reducing and topping of water to maintain proper water quantity, maintenance of proper oxygen level of $5.0-9.5 \mathrm{mg} / \mathrm{l}$, maintenance of good pH level of 6.5 to $8.55 \mathrm{mg} / /$, maintenance of proper water temperature of $20-30^{\circ} \mathrm{C}$ ) by the fish farmers were $4.77,4.92,4.79,3.87,4.00$ and 4.00 respectively, out of a maximum of a 5-point scale. The grand mean adoption score for the fish farm management technologies was 4.41 , indicating that the fish farmers were at the trial level of the adoption process. The adoption index was $88.0 \%$, implying that the adoption level of the farmers was above average. This agrees with the findings of Tawari et al (2009) which stated that the GRP fish farming unit help the farmers to maintain their pond water quality.

The high adoption level could mean that the fish farmers test their pond water to ensure maintenance of good water quality. The low adoption mean scores for maintenance of proper oxygen level, proper $\mathrm{pH}$ level and proper temperature level may be that these technologies require technical skills. 
Table 2: Distribution of farmers according to adoption of GRP fish farming technologies

Fish farming techniques

\begin{tabular}{lll}
$\begin{array}{l}\text { Adoption } \\
\text { mean }\end{array}$ & $\begin{array}{l}\text { Grand } \\
\text { mean }\end{array}$ & $\begin{array}{l}\text { Adoption } \\
\text { index }\end{array}$ \\
score & score & \\
\hline
\end{tabular}

Fish farm management

Proper site selection considering source of good water

4.29

pond construction (size) such as depth of $75 \mathrm{~cm}-2 \mathrm{~m}$ deep

4.27

Proper use and provision of harvesting tools

2.76

3.96

0.79

Good record keeping technique

4.12

Training on the need for cooperatives societies

4.40

Feeding technique

Use of different sizes of feed like $0.5 \mathrm{~mm}$ at first week 4.88

Use of good feed like copen

Use of correct quantity of feed

4.59

4.30

3.05

Training farmers to produce locally made feed

2.44

Fish culture management

Fish seed multiplication technique

2.84

Stocking techniques like avoiding overstocking

Trainings on selection of good fish species like tilapia and catfish

4.69

4.70

4.59

Training on Grading techniques

3.05

Training on medication and disease control

3.83

Advice on fish harvesting techniques (proper time and weight of $1 \mathrm{~kg}$ )

3.32

3.31

Training and helping farmers to obtain credit

Provision of Fingerling like tilapia and catfish

4.26

Water quality and quantity management

Maintenance of proper oxygen level of $5.0-9.5 \mathrm{mg} / \mathrm{l} \quad 3.87$

Maintenance of good pH level of 6.5 to $8.55 \mathrm{mg} / \mathrm{l} \quad 4.00$

Maintenance of proper water temperature of 20-300c 4.10

Water testing to ensure quality standard $\quad 4.77$

Changing of bad water

4.92

Reducing and topping of water to maintain proper water quantity $\quad 4.79$

Liming technique

use of liming materials to buffer water $\mathrm{pH} \quad 3.70$

Use of liming to reduce muddy water $\quad 3.47$

Liming to fertilize pond $\quad 2.83$

Use of right type of liming material like: hydrated lime $\mathrm{Ca}(\mathrm{HO})_{2}$, and 2.95

quick lime Cao

Use of ground limestone at the rate of $1104 \mathrm{~kg} / \mathrm{ha} \quad 2.23$

Use of agricultural lime at the rate of $2270 \mathrm{~kg} / \mathrm{ha} \quad 2.01$

Use of hydrated lime of $114 \mathrm{~kg} / \mathrm{ha}$

2.00

Use of quicklime of $200 \mathrm{~kg} / \mathrm{ha}$

1.99

\section{Liming technique}

The use of liming materials to buffer water $\mathrm{pH}$ had adoption mean score of 3.70 , implying that they were at the trail level. Use of liming to reduce muddy water, liming to fertilize pond and the right type of liming material to use like: hydrated lime $\mathrm{Ca}(\mathrm{HO}) 2$, quick lime Cao and wood ash had mean adoption score of 3.47, 2.83 and 2.95 respectively on a 5 point scale indicating that they were still the evaluation level of the adoption process.

Adoption mean scores for pond liming techniques (Use of liming materials to buffer water $\mathrm{pH}$, use of liming to reduce muddy water, liming to fertilize pond, use of right type of liming material like hydrated lime $\mathrm{Ca}(\mathrm{HO})_{2}$ and quick lime $\mathrm{CaO}$, use of ground limestone at the rate of $1104 \mathrm{~kg} / \mathrm{ha}$, use of agricultural lime at the rate of $2270 \mathrm{~kg} / \mathrm{ha}$, use of hydrated lime 
of $114 \mathrm{~kg} / \mathrm{ha}$ and use of quicklime of $200 \mathrm{~kg} / \mathrm{ha}$ ) by the fish farmers were $3.70,3.47,2.83$, $2.95,2.23,2.01,2.00$ and 1.99 respectively, out of a maximum of a 5-point scale. The grand mean adoption score for the fish farm management technologies was 2.65, indicating that the fish farmers were at the interest level of the adoption process. The adoption index was $52.0 \%$ portraying that the adoption level of the farmers was slightly above average. This supports Nlerum (2013) who found that majority of the farmers do not use liming techniques. This implies that they were still at the interest stage for use of the different liming materials.

\section{Constraints to adoption of fish farming technologies disseminated by GRP}

Data in Table 3 show the result of the varimax rotated component matrix indicating the extracted factors based on the perceived constraints to adoption of disseminated technologies. Four (4) major constraints were extracted. Variables with loading of 0.40 and above at $10 \%$ overlapping variance were used in naming the constraints.

Technology dissemination constraints include constraining variables like: results of use of some improved technology cannot be seen (0.832), poor income from fishes produced with GRP fingerlings (0.760), poor output from use of GRP fingerlings (0.639), cultural barrier between beneficiaries and GRP contact persons (0.598), existence of technologies better than the GRP improved technology (0.536) and inadequate communication channel for contacting GRP staff (0.450). The type of technology disseminated and method of dissemination used affect the adoption of the technology.

The project implementation and sustainability constraints include variables such as: reduction of attention given to old beneficiary fish farmers (0.921), GRP extension workers do not fulfil their promises with regards to time of visitation (0.881), consumers' preference for wild fish to cultured fish (0.763), non-availability and accessibility of commercial feed (0.667) and losses of fish due to attack by predators. Reduction of attention given to old beneficiary fish farmers loaded highest. This is similar to the finding of Tawari et al (2009) who noted that insufficient contact with GRP staff was a militating problem of beneficiaries of the project.

Variables that loaded under factor 3 (input related constraints) were late arrival of GRP inputs (0.760), losses of fishes due to flood (0.568), Inadequate supply of inputs by GRP (0.581), high cost of recommended feed (0.516) and the technology cannot be tried on a small scale (0.477). Late arrival of GRP inputs loaded highest among the input related constraints. This agrees with Anene, Ezeh and Oputa (2010) in which inadequate assess to inputs was major problems fish farmers.

Organizational constraints (factor 4 ) include variable such as inability of GRP contact person to teach the technology properly (0.853), complexity of the fish farming technologies disseminated by GRP (0.773) and inaccessibility to credit for fish farming $(-0.794)$. This is in line with the finding of Nlerum (2013) in which inability of GRP contact person to teach the technology properly and inaccessibility to project micro-credit facilities were the militating problems of beneficiaries of the GRP. 
Table 3: Constraints to adoption of GRP fish farming technologies by fish farmers

\begin{tabular}{|c|c|c|c|c|}
\hline \multirow[t]{2}{*}{ Variable } & \multicolumn{4}{|c|}{ Component } \\
\hline & & & 3 & 4 \\
\hline $\begin{array}{l}\text { Inability of GRP contact person to teach the technology } \\
\text { properly }\end{array}$ & 0.133 & 0.091 & 0.050 & 0.853 \\
\hline $\begin{array}{l}\text { Complexity of the fish farming technologies disseminated } \\
\text { by GRP }\end{array}$ & 0.206 & -0.126 & 0.177 & 0.773 \\
\hline $\begin{array}{l}\text { There are other technologies better than the GRP } \\
\text { technologies }\end{array}$ & 0.536 & -0.023 & -0.068 & -0.059 \\
\hline Losses of fish due to flood & -0.069 & 0.118 & 0.568 & 0.069 \\
\hline Some of the technologies cannot be tried on a small scale & 0.248 & 0.088 & 0.477 & -0.305 \\
\hline $\begin{array}{l}\text { The results of use of some GRP improved technology } \\
\text { cannot be seen }\end{array}$ & 0.832 & 0.077 & 0.042 & 0.001 \\
\hline $\begin{array}{l}\text { Inadequate communication channel for contacting GRP } \\
\text { staff }\end{array}$ & 0.450 & -0.135 & 0.311 & -0.123 \\
\hline Insufficient trained extension personnel & -0.015 & 0.105 & 0.331 & 0.750 \\
\hline $\begin{array}{l}\text { Cultural and language barrier between beneficiaries and } \\
\text { GRP contact persons }\end{array}$ & 0.598 & 0.185 & -0.087 & 0.261 \\
\hline Poor output from use of GRP fingerlings & 0.639 & -0.002 & 0.173 & 0.159 \\
\hline Poor income from fishes produced with GRP fingerlings & & 0.215 & -0.122 & 0.060 \\
\hline Late arrival of supplied GRP inputs & -0.105 & 0.016 & 0.760 & -0.001 \\
\hline Inadequate supply of inputs by GRP & -0.034 & 0.146 & 0.581 & 0.389 \\
\hline Inaccessibility to credit for fish farming & 0.124 & 0.160 & 0.176 & -0.794 \\
\hline High cost of recommended feed & -0.049 & -0.075 & 0.516 & -0.241 \\
\hline Losses of fish due to attack by predators & 0.071 & 0.468 & 0.217 & 0.365 \\
\hline Consumers' preference for wild fish to cultured fish & 0.130 & 0.763 & 0.192 & -0.046 \\
\hline Non-availability and accessibility of commercial feed & 0.208 & 0.667 & -0.170 & -0.307 \\
\hline Reduction of attention given to old beneficiary fish farmers & 0.017 & 0.921 & 0.110 & -0.077 \\
\hline $\begin{array}{l}\text { GRP extension workers do not fulfil their promises with } \\
\text { regards time of visitation }\end{array}$ & -0.015 & 0.881 & 0.036 & 0.048 \\
\hline
\end{tabular}

Factor $\mathbf{1}=$ technology dissemination constraints; $\mathbf{2}=$ project implementation and sustainability constraints; $\mathbf{3}=$ Input related constraints and $\mathbf{4}=$ organizational constraint

\section{Socio-economic characteristics of farmers influencing adoption of fish farming technologies}

Data in Table 4 show that from the regression results, there was a significant relationship $(F=11.076 ; p \leq 0.05)$ between the socioeconomic characteristics of the fish farmers and adoption of disseminated fish farming technologies. The variables were age (years), number of people living in their household, years spent in formal education, years of participation in GRP, membership of social organisation and number of contact with GRP personnel per month.

Entries in Table 4 show that age of the farmers $(t=3.602 ; p=0.023)$, years spent in formal education ( $t=2.785 ; p=0.021)$, years of participation in GRP ( $t=3.962 ; p=0.000)$, were positively significant and influenced the adoption of the fish farming technologies. This result connotes that increases in the magnitude of any of the above variables will lead to increase in adoption among the beneficiaries of the project. Number of people living in their household ( $t=2.458 ; p=0.500$ ) was not significant and did not influence the adoption of the fish farming technologies. Membership of social organisation $(t=1.465 ; p=0.05)$ and number 
of contact with GRP personnel per month $(t=1.348 ; p=0.05)$ were not significant and did not influence the adoption of the fish farming technologies.

Age of the fish farmers had positive influence on adoption of GRP fish farming technologies. This agrees with findings of Langy and Mekura (2005) who reported that older farmers have higher accumulated capital, more contacts with extension workers, better preferred by credit institutions and larger family size, all of which may make them more prepared to adopt technology more than younger ones. This finding contradicts Ume, Uloh, and Okoronkwo (2009), who opined that older farmers are less amendable to change and hence reluctant to change the status quo which have negative impact on adoption. Age of farmers can affect their decision to adopt new technologies. The respondents were in their economically active stage. This helps them to decide on whether to adopt a technology.

Also, there was a positive significant relationship between years spent in formal education and adoption of GRP fish farming technologies in the area. This is similar to the findings of Okoronkwo and Ume (2013) in which the level of farmers' education has profound effect on the catfish farming technology adoption. The effect could be related to the fact that educated farmers are more responsive to positive changes in farming trends and risk averse (Ewuziem, Onyenobi, and Ironkwe, 2010). Formal education can increase productivity and enhances the farmers' ability to understand and evaluate new production techniques.

Years of participation in GRP also had positive influence on the adoption of the technologies by the farmers. Extension is the major medium for agricultural innovations dissemination to farmers from the research. This finding contradicts Eze and Akpa (2010), who cited that there was inadequate transfer of information to farmers by extension agent due to bottle necks such as negative attitude of the extension agents to their works and inadequate motivation by appropriate quarter, affect technology transfer and consequent adoption. It could be that the number of years they participated in GRP increases their knowledge on fish production.

There was no significant relationship between number of people living in the respondents' household and the adoption of the GRP technologies. This is contrary to the finding of Okoronkwo et al (2013) in which family size had a positive relationship with catfish farming technology adoption

The R Square value (0.356) in Table 4 indicates the proportion of variability in the adoption of the fish farming technologies which were accounted for by the multiple regression equation. The adjusted $R$ square $(0.346)$ is an estimated $r^{2}$ for the population. Nearly $34 \%$ (adjusted $R$ square) of the variance in adoption of the fish farming technologies is explained by the variables included in the model.

The $B$ value is the regression coefficients for the variables (example, age (0.002)), but these values do not show the level of importance of each predictor variable. The level of importance is shown when the B value have been transformed into standard scores (beta B values). Therefore the standardizes coefficients Beta reveal that years of participation in GRP (0.137) had much influence on adoption of GRP fish farming technologies than age of fish farmers (0.087) and the number of years spent in formal education (-0.094).

Number of people living in the households, membership of social organisation and number of farmers' contact with GRP personnel per month had no influence on adoption of GRP fish farming technologies. This implies that these variables do not add to the ability to predict adoption of the GRP fish farming technologies in the study area. In view of these findings, the null hypothesis was accepted for the non-significant variables.

The regression results show that some socioeconomic characteristics of the respondents' (age (years), years spent in formal education and years of participation in 
GRP) influenced the adoption of the fish farming technologies. Therefore, the null hypothesis was rejected for these variables. 
Table 4: Socio-economic characteristics of GRP fish farmers influencing adoption of GRP fish farming technologies

\begin{tabular}{|c|c|c|c|c|}
\hline \multirow[t]{2}{*}{ Variables } & \multicolumn{2}{|c|}{$\begin{array}{l}\text { Unstandardized } \\
\text { Coefficients }\end{array}$} & \multirow{2}{*}{$\begin{array}{l}\text { Standardized } \\
\text { coefficients } \\
\text { Beta }\end{array}$} & \multirow[t]{2}{*}{ T-value } \\
\hline & B & $\begin{array}{l}\text { Std. } \\
\text { Error }\end{array}$ & & \\
\hline (Constant) & 3.671 & 0.270 & -0.051 & 13.602 \\
\hline Age & 0.002 & 0.005 & 0.087 & $3.602^{*}$ \\
\hline $\begin{array}{l}\text { Number of people living in your } \\
\text { household }\end{array}$ & 0.015 & 0.019 & -0.022 & 2.458 \\
\hline Years spent in formal education & -0.002 & 0.009 & -0.094 & $2.785^{*}$ \\
\hline Years of participation in GRP & -0.015 & 0.015 & 0.137 & $3.962^{*}$ \\
\hline Membership of social organization & 0.006 & 0.059 & 0.008 & 1.465 \\
\hline $\begin{array}{l}\text { Number of contact with GRP } \\
\text { officials in a month }\end{array}$ & 0.014 & 0.010 & -0.051 & 1.348 \\
\hline
\end{tabular}

a. Dependent variable: adoption scores. $\mathrm{R}$ square $=0.356$; adjusted $\mathrm{R}$ square $=0.346$; F-value $=11.076 ; p \leq 0.05,{ }^{*}$ significant

\section{Conclusion and Recommendation}

Majority of the fish farmers were middle aged, married and educated. Majority of fish farmers adopted most of the technologies disseminated by GRP on fish farm management techniques, fish feeding techniques etc. The constraints to adoption of the fish farming technologies disseminated by GRP were technology dissemination constraints; project implementation and sustainability constraints; Input related constraints and organizational constraint. Based on the findings of the study, the following recommendations were made: The GRP personnel should endeavour to provide extension service to many fish farmers in the area including female farmers in order to boost their productivity. The GRP personnel should be trained on latest technologies and provided with sufficient input (including fingerling) for the services. Farmers should be given sufficient fingerlings at the right time and also incentives for feed procurement or production. There should be more training for farmers on ways of formulating feed locally at a cheaper rate in order to reduce the effect of high cost of feed.

\section{References}

Amaniyie, V. (2006). The struggle of the Niger Delta, Nigeria. Owerri: Springfield Publishers Limited. xvi-xviii.

Anene, A, Ezeh, C.I. and C. O Oputa (2010). Resources use and efficiency of artisanal fishing in Oguta, Imo State, Nigeria. Journal of Development and Agricultural Economics. 2(3):094-099. http://www.academicjournals.org/JDAE.

Apata, O.M. (2012). Awareness and adoption of fish production technologies in south western, Nigeria. Journal of Emerging Trends in Engineering and Applied Sciences (JETEAS). 3(5):819-822.

Anene, A, Ezeh, C.I. and C.O Oputa (2010). Resources use and efficiency of artisanal fishing in Oguta, Imo State, Nigeria. Journal of Development and Agricultural Economics. 2(3):094-099.

Aphunu, A and Otoikhian (2008). Farmers' perception of the effectiveness of extension agents of Delta State Agricultural Development Programme (DADP). African Journal of General Agriculture. 4(3). http://www.asopah.org 
Barrett, C.B., Reardon, T. and Webb, P. (2001). Nonfarm income diversification and household livelihood strategies in rural Africa: concepts, dynamics, and policy implications. Food Policy 26 (4): 315-331.

Davies, R.M., Davies, O.A., Inko-Tariah, M.B. and Bekibele, D.O. (2008). Mechanization of fish farms in Rivers State, Nigeria. World Applied Sciences Journal. 3(6):926-929.

Etuk, U. R., Ekanem, J.T., and Cookey, I.,M. (2012). Analysis of the contribution of Green River Project to agricultural and rural development in Rivers State. African Journal of Agriculture Technology and Environment - AJATE, 1(1): 59-64.

Ewuziem, J.E; Onyenobi, V.O. and Ironkwe, A.G. (2010): Technical efficiency of pig farmers in Imo State, Nigeria. A translog stochastic frontier production function approach. Nigeria Agricultural Journal. 41(1): $138-145$.

Eze, C.I. and Akpa, C.E. (2010) Analysis of technical efficiency of national fadama 11 facility on arable crop farmers in Imo State, Nigeria. 41(1): 108-114.

Green Rivers Project (GRP) (2001). A review of green river project. Rivers State, Nigeria: Nigerian Agip Oil Company Limited. http://www.eni.com.

Gupta M. V, Bartley D. M and Acosta B. O (2004). Use of genetically improved and alien species for aquaculture biodiversity in Africa. World Food Centre. p.107.

Koyenikan, M.C.(2008). Issues for agricultural extension policy in Nigeria. Journal of Agricultural Extension, 12 (2): 53-62.

Langy, A and Mekura, M (2005). Modelling agricultural technology adoption using the software STAT. A paper presented at a training course organised by CIMMUT-ALP for it's NARS partners in Southern Africa on econometric application of modelling technologies

Nlerum, F. E (2013). Determinants of adoption of agricultural extension of green river project among rural households of Niger Delta, Nigeria. Journal of Agricultural Science and Technology B 3(2013) pp284-288.

Nnodim, U. A and Isife, B. I. (2004). "Assessment of shell petroleum development company extension services in Etche Local Government Area of Rivers State, Nigeria". Journal of Agriculture and social Research. 4(2): 19-23.

Nwachukwu, I and Onuegbu, R(2007). Adoption of aquaculture technology by fish farmers in Imo State, Nigeria. Journal of Technology Studies. 33(1),Pp57-64.

Ogunlade, I. Oladele O.I and Ogunsola M. B. (2009). Impact of Green River Project on livelihood of farmers in Rivers State Nigeria. Journal of Human Ecology. 26(2): 8184. Available online at http://www.krepublishers.com

Okoronkwo M.O. and Ume S.I. (2013). Evaluation of the socioeconomic factors influencing adoption of catfish production technologies in Anambra State, Nigeria. Int'l Journal of Agric. and rural development. 16 (1):1425-1430.

Rogers, M.E. (2003). Diffusion of innovation. Fifth (ed). New York Free Press.

Tawari C.C. (2006). Effectiveness of agricultural agencies in fisheries management and production in the Niger Delta. Doctor of Philosophy (Ph.D) thesis, Rivers State University of Science and Technology, Port Harcourt, Nigeria (Unpublished).180pp.

Ume, S.I, Uloh, V.E. and Okoronkwo, M.O. (2009): Adoption of improved rice production technologies by farmers in Anambra State. Ebonyi Technology and Vocational Education Journal. 3(1): $1-7$. 